\title{
Comparative Advantages of Czech AFT in Relation to Value and Volume of Realized Trade
}

\author{
Michal STEININGER, Luboš SMUTKA, Mansoor MAITAH \\ Czech University of Life Sciences Prague, Prague, Czech Republic \\ \{steininger, smutka, maitah\} @pef.czu.cz
}

\begin{abstract}
The goal of this article is to identify the most significant changes, which occurred in selected territories within the Czech agrarian foreign trade (AFT). The analysis also includes an element related to the development and situation of unit prices and the physical volume of AFT as well. The differences which exist in relation to long-term trade partners of the Czech AFT, are observed. From individual analyses, it's then possible to work on certain assumptions, necessary for the analysis of competitiveness, and more precisely the comparative advantages on the part of Czech AFT. These comparative advantages are primarily based on the ability of the Czech Republic to compete within the sector of product exporting with a lower rate of production, where the export strategies rely mainly on high volumes of exported mass and low export prices. This fact is then confirmed by analyses made possible through the LFI, RCA and TBI indices. The most noteworthy partners of the Czech AFT are the developed countries, particularly the member countries of the OECD and more significantly the EU28. It's possible to detect the deterioration of the coverage of unit prices of imports by the unit prices of exports. Due to the high growth dynamics of the export volume, it's possible to observe a noticeable and long lasting improvement, when it comes to the coverage of the value of imports by values of exports. In addition, this is visible in the relationship to the coverage of import volumes by export volumes.
\end{abstract}

Keywords: Agrarian Foreign Trade (AFT), Comparative Advantage, Volume, Value, Price, Coverage of Imports by Exports, Czech Republic, OECD, EU28, world, CIS.

\section{Introduction}

In the last two decades, The Czech agrarian trade has undergone a very substantial transformation [3]. This transformation was significantly influenced by several dynamically developing factors, which originate not only in the area of economics, but also in the political and social spheres [4]. This pattern was primarily influenced by a large number of factors connected with the admission of the Czech Republic to the EU, and also by the direction of the Common Agricultural and Common Trade policies of the EU countries [9]. The agrarian trade was influenced by, not only the reforms conducted on the EU level, but also by reforms realized on the level of the 
national economy and national policies [13]. Last but not least, the agrarian trade was also influenced by the market situation of third countries. Another important element affecting the Czech agrarian trade is the globalization of the world economy, especially the agrarian and food markets [12]. In this regard, it is necessary to emphasize the influence of multinational capital and foreign investments on the shaping of the current state of the Czech agrarian sector, in particular the food industry. It is the large multinational companies, who to a great extent determine the level of Czech agrarian and food trade, and by their actions also influence the direction of the trends that the Czech agrarian market follows [8]. An example of such company is Phillip Morris, the parent company of Tabák Kutná Hora a.s.. In the past few years the Czech Agrarian trade has undergone a very significant transformation process, which has been influenced not only its territorial boundaries, but also the commodity structure and in large part is also reflected in the structure of the Czech agrarian trade in the terms of degree of processing of the traded products. It is mainly the structure of the trade, which in the case of the Czech Republic, is of an extreme characteristic and does not correspond with the standards, which are common to developed countries [11]. When it comes to the development in terms of volume and value of the Czech agro trade, it is the Czech Republic that shows distinctive particularities compared to a number of other countries, especially in the EU environment. This fact must then logically be projected into the area of the competitiveness of the Czech agrarian and food trade, which primarily slips its way into the international market through relatively low kilogram prices. With this in mind, it is important to mention the specific characteristics of the distribution of the comparative advantages of the Czech agro trade. The Czech Republic generally has no obvious comparative advantage, however on the level of selected commodity aggregates, these comparative advantages exist, especially in regards to relationship with member countries of the EU. It is a paradox, that when it comes to the European market, which is very lucrative, the Czech Republic makes its way through only to a limited extent by the export of products with higher values added. In addition, it dominates through the unprocessed and semi-finished goods. On the other hand, in relation to third countries, particularly countries outside Europe, the commodity structure is mainly focused towards exporting products with higher degree of processing and higher unit prices. In this regard, it is necessary to mention the Czech agrarian trade is to a great extent disadvantaged in comparison to a number of its competitors [11]. This is because of the fact that the Czech Republic is a "landlocked country", without sea access, which in a very significant way limits the export potential of the Czech agrarian and food products in relation to non EU regions. The importance of third countries is constantly decreasing. The last really significant nonEU partner Russian federation is constantly reducing its share in Czech agrarian trade. The importance of Russia is reduced because of political consequences [10] and because of Russian market specifics [5,6]. A specific paradox of the Czech agrarian trade is its growth through trend, which is primarily built, not on the growth of export of products with a higher degree of processing and higher unit prices, but rather on the continuous growth of the volume of the exported mass. This creates a contradictory situation in the area of the balance of final trade, because if we approach 
the assessment of the balance of trade in terms of development of the value, then the value is permanently and significantly negative. On the other hand, if we were to assess the balance of trade in terms of volume of traded mass, then the Czech agrarian trade has a long term surplus. The problem of the Czech agrarian trade then becomes the extreme differences concerning the per kilogram prices of realized exports and imports. However, there are significant differences in relation to individual groups of countries, which represent the trading partners of the Czech agro trade.

\section{Data and methods}

This article is focused on the issues of the transformation of the commodity structure of the Czech agrarian trade from 2001 until 2016. The structure of the article is divided into four parts. Firstly, the analysis of the restructualization of the commodity structure of the Czech agrarian trade is conducted and compared to all trade partners. Secondly, the commodity structure is separately analyzed and compared to the EU countries vs. third countries (all non-member countries of EU28). In the third portion, the article provides a comparison of changes in the area of the commodity structure compared to developed countries (OECD) vs. developing countries (non-member countries of OECD). Last but not least, the analysis is conducted with the emphasis on Europe. An analysis, in addition to the restructualization of the commodity structure in relation to EU countries, the restructuralization in relation to the CIS countries (countries of Common Independent States) and also in relation to the other European countries is conducted. Our analysis is accomplished through the application of the 'product mapping' approach. The analysis in this regard is achieved through the calculation of RCA, LFI and TBI indices. Its application then makes it possible to divide the commodity structure into four segments, according to their comparative advantages and value of balance.

The aim of the article is to identify the most significant changes, which occurred in relation to the selected territories. The changes are interpreted not only in the traditional values concept, but in addition the analysis also includes an element related to the development and states of unit prices and physical volume of agrarian trade. Incidentally, the differences among individual groups of countries, which represent the long-term trade partners of the Czech agrarian trade, are observed.

We applied the HS system: HS01 Live animals, HS02 Meat and edible meat offal, HS03 fish and crustaceans, mollusks and other aquatic invertebrates, HS04 Dairy produce birds' eggs natural honey edible products of animal origin, not elsewhere specified or included, HS05 Products of animal origin, not elsewhere specified or included, HS06 Live trees and other plants bulbs, roots and the like cut flowers and ornamental foliage, HS07 Edible vegetables and certain roots and tubers, HS08 Edible fruit and nuts peel of citrus fruit or melons, HS09 Coffee, tea, mate and spices, HS10 Cereals, HS11 Products of the milling industry malt starches inulin wheat gluten, HS12 Oil seeds and oleaginous fruits miscellaneous grains, seeds and fruit industrial or medicinal plants and fodder, HS13 Lac gums, resins and other vegetable saps and extracts, HS14 Vegetable plaiting materials vegetable products not elsewhere specified or included, HS15 Animal or vegetable fats and oils and their cleavage 
products prepared edible fats animal or vegetable waxes, HS16 Preparations of meat, of fish or of crustaceans, mollusks or other aquatic invertebrates, HS17 Sugars and sugar confectionery, HS18 Cocoa and cocoa preparations, HS19 Preparations of cereals, flour, starch or milk pastry cooks' products, HS20 Preparations of vegetables, fruit, nuts or other parts of plants, HS21 Miscellaneous edible preparations, HS22 Beverages, spirits and vinegar, HS23 Residues and waste from the food industries prepared animal fodder, HS24 Tobacco and manufactured tobacco substitutes. Data sources for individual analyses: UN COMTRADE, Czech statistical office. Collected data cover the following categories: export and import value and volume, unit value of realized exports and imports.

This paper evaluates through, the use of basic statistical indicators, the general development trends of export and import value and volume. The other analysed categories are export/import coverage ratio, export and import unit value development. An important part of the analysis is related to the problem of comparative advantages distribution. The goal of this paper is to specify the main driving force of Czech agrarian trade value development. In this case, the paper specifies whether that main driving force of Czech agrarian trade value is unit value of traded products or volume performance. The analyses is performed in relation to above specified groups of countries representing the trade partners of the Czech Republic. The basic indicator applied to discover the actual state of Czech agrarian trade comparative advantages distribution is the standard RCA index (proposed by [2] and later modified by [1]):

$$
R C A_{j}^{i}=\frac{x_{j}^{i}-m_{j}^{i}}{\sum_{l=1}^{N} x_{j}^{i}+m_{j}^{i}} / \frac{\sum_{j=1}^{N} x_{j}^{i}-\sum_{j=1}^{N} m_{j}^{i}}{\sum_{l=1}^{N} x_{j}^{i}+\sum_{j=1}^{N} m_{j}^{i}}
$$

where $\mathrm{x}_{\mathrm{j}}^{\mathrm{i}}$ and $\mathrm{m}_{\mathrm{j}}^{\mathrm{i}}$ represent country $i$ 's export and import of product $j \cdot \operatorname{RCA}_{\mathrm{j}}^{\mathrm{i}}>1$ indicates country $i$ has a comparative advantage in production of $j$; the greater the index, the stronger the advantage. $\mathrm{RCA}^{\mathrm{i}}{ }_{\mathrm{j}}<1$ indicates that country $i$ has a comparative disadvantage in production of $j$; the smaller the index, the greater the disadvantage. The advantage of RCA index is its ability to identify comparative advantages/disadvatages existing at general level, but $i$ is not able to identify the partinal comparative advantages existing only at the bilateral level.

The next index used in the paper is Lafay index [7]. Using this index we consider the difference between each item's normalized trade balance and the overall normalized trade balance. Unlike the above indexes, Lafay index does not take into account world variables. Using LFI index we can focus on the bilateral trade relations between the countries and the regions. Moreover, this index is more reliable on the over-time comparison of sectors within a country. The Lafay index helps us to understand how the comparative advantages over time and to compare strength of comparative advantage of individual products and product groups, for individual regions and countries.

For a given country, $i$, and for any given product $j$, the Lafay index is defined as: 


$$
L F I_{j}^{i}=100\left(\frac{x_{j}^{i}-m_{j}^{i}}{x_{j}^{i}+m_{j}^{i}}-\frac{\sum_{j=1}^{N}\left(x_{j}^{i}-m_{j}^{i}\right)}{\sum_{j=1}^{N} x_{j}^{i}+m_{j}^{i}}\right) \frac{x_{j}^{i}+m_{j}^{i}}{\sum_{l=1}^{N} x_{j}^{i}+m_{j}^{i}}
$$

where $\mathrm{x}_{\mathrm{j}}^{\mathrm{i}}$ and $\mathrm{m}_{\mathrm{j}}^{\mathrm{i}}$ are exports and imports of product $j$ of country $i$, towards and from the particular region or the rest of the world, respectively, and $N$ is the number of items. Positive values of the Lafay index indicate the existence of comparative advantages in a given item; the larger the value the higher the degree of specialization [15].

The next part of the analysis presented in this paper was conducted using the analytical tool, named "products mapping". This tool enables to assess leading exported products from two different points of view, i.e. domestic trade-balance and international competitiveness [14]. Product mapping approach is based on application of two different indices: LFI index and TBI index.

Trade Balance Index (TBI) is employed to analyze whether a country has specialization in export (as net-exporter) or in import (as net-importer) for a specific group of products. TBI is simply formulated as follows:

$$
T B I_{j}^{i}=\frac{x_{j}^{i}-m_{j}^{i}}{x_{j}^{i}+m_{j}^{i}}
$$

where $\mathrm{TBI}^{\mathrm{i}}{ }_{\mathrm{j}}$ denotes trade balance index of country $i$ for product $j$; $\mathrm{x}_{\mathrm{j}}^{\mathrm{i}}$ and $\mathrm{m}_{\mathrm{j}}^{\mathrm{i}}$ represent exports and imports of group of products $j$ by country $i$, respectively [7]. A country is referred to as "net-importer" in a specific group of product if the value of TBI is

\begin{tabular}{|c|c|c|c|}
\hline \multirow{2}{*}{ 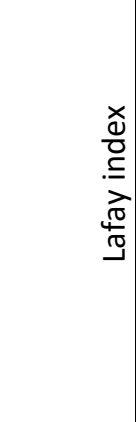 } & $\begin{array}{l}0 \\
\frac{\Lambda}{4} \\
ت\end{array}$ & \begin{tabular}{l}
\multicolumn{1}{c}{ Group } \\
Comparative \\
Advantage \\
Net-importer \\
$($ LFl $>0$ and $T B \mid<0)$
\end{tabular} & $\begin{array}{l}\text { Group } \\
\text { Comparative } \\
\text { Advantage } \\
\text { Net-exporter } \\
(\text { LFI }>0 \text { and TB }>0 \text { ) }\end{array}$ \\
\hline & $\frac{O}{\underline{v}}$ & \begin{tabular}{l}
\multicolumn{1}{c}{ Group } \\
Comparative \\
disadvantage \\
Net-importer \\
$($ LFI<0 and TBI<0)
\end{tabular} & \begin{tabular}{l}
\multicolumn{1}{c}{ Group } \\
Comparative \\
disadvantage \\
Net-exporter \\
$($ LFI $<0$ and TB|>0)
\end{tabular} \\
\hline \multirow{2}{*}{\multicolumn{2}{|c|}{$\begin{array}{l}\text { Czech Agrarian Foreign Trade } \\
\text { Commodity Structure }\end{array}$}} & $\mathrm{TBI}<0$ & TBI $>0$ \\
\hline & & \multicolumn{2}{|c|}{ Trade Balance Index } \\
\hline
\end{tabular}
negative, and as "net-exporter" if the value of TBI is positive [14].

Fig. 1. Modified product mapping scheme

The figure 1 represents a matrix for the distribution of the entire set of exported products into 4 groups according to the two selected indicators (LFI and TBI). LFI index is chosen for "product mapping" approach because of its ability to take in 
consideration only those transactions which are really related to individual countries' trade performance (in this case the Czech Republic's trade performance). The TBI index is applied for its ability to divide the products according to their real trade performance into above specified four quadrants. The chosen approach provides a possibility to specify the comparative advantages on the base of real bilateral trade performance (in relation to selected group of partners).

\section{$3 \quad$ Results and discussion}

Between 2001 and 2016, the value of the turnover of conducted transactions increased from about CZK 118 billion to about CZK 426 billion. During the monitored period, the balance was about CZK 20 billion. The negative balance of turnover decreased from about $17 \%$ to about $5 \%$. The volume of agricultural exports increased from about 3.1 million tonnes to more than 16.1 million tonnes, while the value increased from CZK 49 billion to CZK 201.6 billion. Significantly higher dynamics were shown in import value growth, from CZK 69 billion to CZK 224 billion, while the volume of realized imports increased from only 3.1 million tons to 7.54 million tons. In the years 2001-2016, the Czech Republic exported approximately 191 million tons of agrarian and food products, while importing only 86 million tons. The Czech export price dropped by about $25 \%$ per kilogram, while the import price increased by about $30 \%$. In the selected period, the negative growth rate of unit prices was recorded primarily for the following commodity aggregates: live animals, meat and edible offal, milk, dairy products and eggs, animal products, cereals, vegetable knitting materials and non-alcoholic beverages. Czech agrarian trade is characterized not only by its own commodity structure, but also by the territorial structure which is oriented towards specific groups of countries against which, the Czech agrarian trade as a whole, is uncompetitive. Nevertheless, the Czech Republic is able to derive comparative advantages at the bilateral level and at the level of specific commodity mix.

The value of the Czech agrarian export, or rather import in relation to EU28 countries increased from CZK 41 billion to CZK 186 billion, or rather from CZK 51 billion to CZK 189 billion between 2001 and 2015. The negative balance of mutual agro-trade was significantly closer to a "balanced" trade, with a negative trade balance falling from around $11 \%$ to $0.9 \%$ over those years. In contrast, in relation to third countries, the value of agrarian exports and imports between the referenced years increased from CZK 8.3 billion to CZK 16.9 billion, and from CZK 18 billion to CZK 32.6 billion. In the case of the EU-28 countries, as export partners of the Czech Republic, most of the values of exports is based on transactions with comparative advantages. Within the segment of aggregations that show the positive value of the LFI and the TBI index, it can be observed that the value of exports and imports grew from CZK 23 billion to CZK 124 billion and from CZK 12.6 billion to CZK 82 billion. The weakness of the Czech trade within this segment of goods is its export structure that is built on high volume items with low added value. The values, which are characterized by trade with third countries, are significantly lower and different in comparison with the EU28 countries. 
In the case of developed countries, the comparative advantage is based on the different position of these items in the overall turnover compared to developing countries. Also, in relation to developing countries, in the last few years the Czech Republic had experienced significant changes in the area of value development and structure of the agrarian trade. This compared to developed countries, where trade is more oriented towards the Czech Republic. It is contradictory, that in relation to developing countries, the Czech Republic reached significantly better price ratios of export/import, than in the case of developed countries. Significant differences also exist in comparison of per kilogram prices of export and import between developed countries and developing countries with focus on a group of aggregates with the framework of segment A and segment D. In relation to the developed countries, the Czech Republic recorded an increase in exports of CZK 23 billion to CZK 109 billion, and an increase in imports from approximately CZK 14.7 billion to approximately CZK 70 billion. In the case of developing countries, the growth of export and import values was much less significant between the observed years from around CZK 7.3 billion to CZK 15.6 billion, respectively CZK 1.1 billion to CZK 7 billion.

In the case of agrarian trade, the share of European countries grew from $83 \%$ to 93\% during the selected period. The share of CIS countries and other European countries were not negligible either. In relation to the CIS countries, export prices between the selected years increased from CZK $18 / \mathrm{kg}$ to CZK $37 / \mathrm{kg}$ and, for other European countries, from CZK 25.2 / kg to CZK $44 / \mathrm{kg}$. Import prices have shifted from CZK 18.6 / kg to CZK 30.2 / kg for CIS countries and from CZK $34.24 / \mathrm{kg}$ to CZK $41.4 / \mathrm{kg}$ for other European countries. The average per kilogram price of exports and imports within the category with comparative advantages increased from approx. CZK 21.8 to about $40 \mathrm{CZK}$ and CZK 17 to CZK 30 respectively. This suggests that, the dynamics of export price growth differed from the average, and that the growth in export value was largely driven by unit price growth rather than by growth in the volume of traded goods in relation to the EU28 countries. Kilogram prices of exports and imports have undergone substantial shifts. The reduction is mainly due to the sanctions imposed by the Russian Federation on the European Union, or more precisely Czech exports to Russia.

The analyses shows a long-term deterioration of the coverage of the unit price of imports in the case of EU28 and OECD countries, but also in relation to developing countries. On the other hand, due to high dynamics of growth in export volume, it is possible to notice permanent improvement in case of coverage of volume of imports by volume of exports. A significant increase in the coverage of value of import by value of exports was recorded in the case of EU28 countries, OECD countries and developing countries. The same situation was also recorded in the case of coverage of volume of imports by volume of exports. 


\section{Conclusion}

The Czech agrarian trade has experienced significant changes in the past years. However, the process of transformation of its territorial and commodity structure has not ended as of yet. The weakness of the Czech agrarian trade is its primary focus on only specific trade partners. This is caused by a number of the following. The Czech Republic is a member of the EU and it agrarian trade is therefore realized under the conditions of the Common trade policy of EU countries in addition to being under the condition of the Single market. Furthermore, the Czech Republic is a typical 'landlocked country' without the access to any large harbors or ports. And yet another reason is that the Czech agrarian trade suffers from its focus on the export of a relatively limited amount of high-volume items, which can be very difficult to export abroad due to its lower per unit price, limited values added and high transaction costs connected with long distances. In the monitored period, Czech agrarian exporting recorded a significant increase in its value and volume in both export and import, where the dynamics of growth in value and volume of exports exceeded the dynamics in growth of imports. Nonetheless, the Czech agrarian trade still suffers from a long term deficit when it comes to the realized value. This, however, does not apply in the case of export and import comparison, when the Czech agrarian trade is in a longterm surplus. The weakness, but at the same token, a comparative advantage of the Czech agrarian export, is its significantly low per kilogram prices, which allows the Czech republic to get through with its exports on many and especially then European countries markets. This situation, although positive on one hand, cannot be perceived as satisfactory due to the inability of the Czech Republic to focus on the exporting of products with a higher degree of processing and therefore a higher value added. This could be considered as a very serious problem, if we take into account, that a developed industrial country usually focuses mainly on export of least process or unprocessed products, which make up the backbone of its exports. If we wanted to understand the characteristics of the Czech agrarian trade and its comparative advantages in more detail, it is necessary to analyze it separately in relation to several different groups of countries. Firstly, it is necessary to analyze the Czech agrarian trade in relation to the EU28 vs. 'third countries'. Secondly, it is necessary to understand the relationship between 'developed countries' vs. 'developing countries'. In addition, it is necessary to focus our attention on trade within Europe and the relationship with former Soviet countries. In this regard, it is necessary to analyze the trade in relation to CIS countries, as well as other European countries not belonging to any association. In this regard, it is then possible to state that the commodity structure of the Czech agrarian trade is significantly different in relation to each group of countries individually. Furthermore, it is necessary to state that even comparative advantages are distributed differently among each of the analyzed segments. Last but not least, it is also necessary to state, that in relation to each individual groups of countries, the source of the comparative advantage is also different. In relation to primarily developed countries, particularly countries of the EU28, the comparative advantages mainly come from low price exports and a high volume of realized trade. In the case of developing countries and countries of CIS, the comparative advantages 
come from products with higher values added and therefore with higher per kilogram prices. In general, it is possible to affirm that from the viewpoint of price levels and the degree of processing of exported agrarian and food production, the Czech Republic achieves better results in relation to countries outside the EU28, whereas in relation to EU countries, the Czech agrarian trade can still be marked as untapped. From the viewpoint of coverage of the value of imports by value of exports, the Czech agrarian trade is constantly improving and reaching for a state of balance. This state is being ensured mainly by the export of items with a lower degree of processing (HS01, HS02, HS04, HS05, HS10 a HS22), in which the Czech Republic reaches trade surplus, in the case of other aggregates (mainly including products with higher degree of processing), the Czech Republic has a long-term trade deficit. This situation points out the necessity for further a transformation of the Czech agrarian trade, so it could be brought closer to the standards typical for developed European countries.

Acknowledgements. This paper was supported by Grant Agency of the Faculty of Economics and Management, Czech University of Life Sciences Prague: Analýza komoditní struktury českého agrárního zahraničního obchodu / Analysis of Czech agrarian foreign trade commodity structure [nr. 20171024].

\section{References}

1. Balassa, B.: Comparative Advantage. Trade Policy and Economic Development, University Press, New York (1991).

2. Balassa, B.: Trade liberalization and "revealed" comparative advantage. The Manchester School of Economics and Social Studies 33(2), 99-123 (1965), DOI: 10.1111/j.14679957.1965.tb00050.x.

3. Bašek, V., Kraus, J.: Czech foreign agricultural trade after joining the European Union. Agricultural Economics 55(12), 583-595 (2009).

4. Burianová, J., Belova, A.: The competitiveness of agricultural foreign trade commodities of the CR assessed by way of the Lafay Index. Agris On-line Papers in Economics and Informatics 4(4), 27-36 (2012).

5. Kharcheva, I., Kontsevaya, S., Maitah, M.: Analysis of manpower resources utilization in agricultural organizations of the Russian Federation. In: Auzina, A. (eds.) INTERNATIONAL SCIENTIFIC CONFERENCE ON ECONOMIC SCIENCE FOR RURAL DEVELOPMENT, vol. 42, pp. 244-249. Latvia University of Agriculture, Jelgava (2016).

6. Kontsevaya, S., Alborov, R., Kontsevaya, S.: Estimation of current status of internal economic control in Russian agriculture. In: Auzina, A. (eds.) INTERNATIONAL SCIENTIFIC CONFERENCE ON ECONOMIC SCIENCE FOR RURAL DEVELOPMENT, vol. 43, pp. 290-295. Latvia University of Agriculture, Jelgava (2016).

7. Lafay, G.: The measurement of revealed comparative advantages. In: Dagenais, M. G., Muet, P. A. (eds.) INTERNATIONAL TRADE MODELING, pp. 209-234. Chapman \& Hill, London (1992).

8. Maitah, M., Řezbová, H., Smutka, L., Tomšík, K.: European Sugar Production and its Control in the World Market. Sugar Tech 18(3), 236-241 (2016). 
9. Pohlová, K., Mezera, J.: Analysis of development of czech foreign trade in foods and beverages. Agris On-line Papers in Economics and Informatics 6(4), 121-131 (2014).

10. Smutka, L., Špička, J., Ishchukova, N., Selby, R.: Agrarian import ban and its impact on the Russian and European Union agrarian trade performance. Agricultural Economics 62(11), 493-506 (2016), DOI: 10.17221/294/2015-AGRICECON.

11. Smutka, L., Steininger, M., Maitah, M., Škubna, O.: The Czech agrarian foreign trade - ten years after the EU accession. In: Smutka, L., Rezbova, H. (eds.) 24th International Scientific Conference on Agrarian Perspectives - Global Agribusiness and the Rural Economy, pp. 385-392. CULS Prague, Prague (2015).

12. Svatoš, M., Maitah, M., Belova, A.: World sugar market-basic development trends and tendencies. Agris On-line Papers in Economics and Informatics 5(2), 73-88 (2013).

13. Svatoš, M.: Selected trends forming European agriculture. Agricultural Economics 54(3), 93-101 (2008).

14. Widodo, T.: Comparative Advantage: Theory, Empirical Measures And Case Studies. Review of Economic and Business Studies (4), 57-82 (2009).

15. Zaghini, A.: Trade advantages and specialization dynamics in acceding countries. Working paper 249, 4-15 (2003) 